\title{
Report on the Göttingen Septuagint
}

\author{
Felix Albrecht \\ Akademie der Wissenschaften zu Göttingen, Göttingen, Germany \\ Felix.Albrecht@uni-goettingen.de
}

\begin{abstract}
This article provides a brief history of the Göttingen Septuagint Editions up to 2019, and focuses on the new Psalter Project "Editio critica maior des griechischen Psalters" (Akademie der Wissenschaften zu Göttingen), which started at the beginning of 2020 . The article illustrates some of the challenges of the planned editorial work, and uses Psalm 1 as a test case. First, an overview is provided of the editorial history, from the earliest printed versions that reveal a major influence of the Lucianic recension, to the Sixtine edition that marks a turning point, followed by all other modern editions (e.g. by Paul Anton de Lagarde and Alfred Rahlfs). Second, attention is drawn to one of the most urgent research tasks, namely the reconstruction of the fragmentary hexaplaric tradition, giving examples of the hexaplaric fragments of Psalm 1 transmitted in ms. Rahlfs 113 (Cod. Ambros. B 106 sup.) and Rahlfs 271 (Cod. Vat. gr. 1747).
\end{abstract}

\section{Keywords}

Septuagint - Psalms - Lucianic Recension - Antiochene Text - Hexapla of Origen Cod. Ambros. B 106 sup. (Rahlfs Ms. 113) - Cod. Vat. gr. 1747 (Rahlfs Ms. 271)

Göttingen can rightly be called the center of Septuagint research in Germanspeaking countries, if not worldwide. For more than one hundred years the major critical edition of the Old Testament in Greek has been prepared in Göttingen. The editorial work can be divided historically into three phases: The first and longest phase is that of the Göttingen "Septuaginta-Unternehmen" (19o82015). After the planned completion of this Göttingen Academy of Sciences and Humanities project in 2015 , editorial work in progress was transferred to a so-called "Forschungskommission," i.e., research commission (2016-2019). On 1 January 2020, a new long-term Academy project came into being that is 
dedicated exclusively to the edition of the Greek Psalter: "Editio critica maior des griechischen Psalters."

This article aims to provide a brief overview of the Göttingen Septuagint until 2019 and focuses on the new Psalter project, which although begun recently has a long prehistory and stands in the Göttingen tradition that goes back to the preparatory works on the Psalter by Paul Anton de Lagarde and Alfred Rahlfs.

The Göttingen Septuaginta-Unternehmen was founded by Alfred Rahlfs (18651935) in 1908. ${ }^{1}$ Its aim was to present a critical edition of the whole Greek Old Testament. Before the official end of the Septuaginta-Unternehmen in 2015, the following text corpora were completed and published: The Pentateuch (1974-1991), edited by John William Wevers (1919-2010) with the assistance of Udo Quast (1939-2005); 2 the prophetic books (1939-1957), edited by Joseph Ziegler (1902-1988); ${ }^{3}$ the wisdom books Sapientia Salomonis (1962), Sapientia Iesu Filii Sirach (1965), and Iob (1983) ${ }^{4}$ by Joseph Ziegler; Ruth (2006) by Udo Quast, ${ }^{5}$ and Paralipomenon liber II (2014) by Robert Hanhart; 6 most of the deuterocanonical books (1959-1960, 1974-1993) by Robert Hanhart, and-at the beginning — also by Werner Kappler (1902-1944). The editions are flanked by detailed textual histories, which appeared up to 2015 in the "Mitteilungen

1 On the history of the Göttingen Septuaginta-Unternehmen, cf. Reinhard Gregor Kratz and Bernhard Neuschäfer, eds., Die Göttinger Septuaginta. Ein editorisches Jahrhundertprojekt, AAWG NF 22, MSU 30 (Berlin: De Gruyter, 2013).

2 Pentateuch: I. Genesis 1974; II.1 Exodus 1991; II.2 Leviticus 1986; III.1 Numeri 1982, ${ }^{2}$ 2020; III.2 Deuteronomium ${ }^{1} 1977,{ }^{2} 2006$. For Wevers, see Albert Pietersma and Peter John Gentry, "John William Wevers (1919-2010). A Biographical Note," BIOscs 43 (2010): 2-4.

3 Libri prophetici:XIII. Duodecim Prophetae ${ }^{1} 1943,{ }^{2} 1967,{ }^{3} 1984$, a new edition by Felix Albrecht is in preparation for print; XIV. Isaias ${ }^{1} 1939,{ }^{2} 1967,{ }^{3} 1983$; XV. Ieremias, Baruch, Threni, Epistula Ieremiae ${ }^{1} 1957,{ }^{2} 1976$, ${ }^{3}$ 2006; XVI.1 Ezechiel ${ }^{1}{ }_{1952}$, ${ }^{2} 1977,{ }^{3}$ 20o6, ${ }^{4}$ 2015; XVI.2 Susanna, Daniel, Bel et Draco ${ }^{1} 1954,{ }^{2} 1999$ (ed. Olivier Munnich).

4 Libri sapientiales: XI.4 Iob 1982; XII.1 Sapientia Salomonis ${ }^{1} 1962,{ }^{2} 1981,{ }^{3}{ }_{2017}$; XII.2 Sapientia Iesu Filii Sirach ${ }^{1} 1965,{ }^{2} 1981,{ }^{3} 2016$. For Ziegler, see Robert Hanhart, "In memoriam Joseph Ziegler," BIoscs 22 (1989): 1-4; Arnim Schmitt, "Erinnerungen an Joseph Ziegler (1902-1988)," $B N 113$ (2002): 69-73.

5 IV.3 Ruth ${ }^{1} 2006,{ }^{2} 2009$.

6 Libri historici: VIII.1 Esdrae liber I ${ }^{1} 1974,{ }^{2} 1991$; VIII.2 Esdrae liber II ${ }^{1} 1993,{ }^{2} 2017$; VIII.3 Esther ${ }^{1} 1966,{ }^{2} 1983$; viII.4 Iudith 1979; VIII.5 Tobit 1983; IX.1 Maccabaeorum liber I (ed. W. Kappler) ${ }^{1}{ }_{1936}{ }^{2}{ }^{1967}$, ${ }^{3}$ 1990; IX.2 Maccabaeorum liber II (copiis usus quas reliquit Werner Kappler edidit Robert Hanhart) ${ }^{1}$ 1959, ${ }^{2} 1976,{ }^{3}{ }_{2008}{ }^{4}{ }_{2017}$; IX.3 Maccabaeorum liber III ${ }^{1} 1960,{ }^{2} 198$ o. 
des Septuaginta-Unternehmens" (MSU; in the period 1909-2015, a total of thirty volumes appeared). In 2015, the Göttinger Septuaginta-Unternehmen was officially closed.

\section{Forschungskommission zur Edition und Erforschung der Septuaginta (2016-2019)}

At the end of 2015 , the Septuaginta-Unternehmen came to its official end. The original task of presenting a full edition of the Greek Old Testament was, however, too big, even for a project that ran for over a century. Therefore, an Academy commission was set up and, from 2016 to 2019, the preparation of the Göttingen editions was overseen by the "Kommission zur Edition und Erforschung der Septuaginta," directed by Reinhard Gregor Kratz and Felix Albrecht. ${ }^{7}$ The commission was given the task of completing the outstanding work of the Septuaginta-Unternehmen. This involved the publication of two new editions: Psalmi Salomonis (ed. Felix Albrecht), and Ecclesiastes (ed. Peter John Gentry). ${ }^{8}$ In the meantime, a number of reprints also appeared. ${ }^{9}$ Unfinished books still in preparation in 2020 are Iosue, Iudices (José Manuel Cañas Reíllo), the Books of Kingdoms (Anneli Aejmelaeus, Tuukka Kauhanen, Pablo Torijano Morales, Julio Trebolle Barrera), Paralipomenon liber I (Timothy Janz), as well as the conclusion of Prouerbia, Canticum (Eva Schulz-Flügel), and Maccabaeorum liber IV (Robert Hiebert). From 2020 onwards, the edition of these books will be conducted by the Robert Hanhart Foundation ("Robert Hanhart-Stiftung zur Förderung der Septuaginta-Forschung"), presided over by Reinhard Gregor Kratz.

7 The reports of the commission are published in the yearbooks of the Academy: Reinhard Gregor Kratz, "Die Erforschung der Septuaginta," in Jahrbuch der Akademie der Wissenschaften zu Göttingen 2016 (Berlin: De Gruyter, 2017), 254-257; idem, "Die Erforschung der Septuaginta," in Jahrbuch der Akademie der Wissenschaften zu Göttingen 2017 (Göttingen: Universitätsverlag, 2018), 190-192; the reports for 2018 and 2019 are in press.

8 Felix Albrecht, ed., Psalmi Salomonis, Septuaginta. Vetus Testamentum Graecum auctoritate Academiae Scientiarum Gottingensis editum XıI.3 (Göttingen: Vandenhoeck \& Ruprecht, 2018); Peter John Gentry, ed., Ecclesiastes, Septuaginta. Vetus Testamentum Graecum auctoritate Academiae Scientiarum Gottingensis editum XI.2 (Göttingen:Vandenhoeck \& Ruprecht, 2019).

9 Sapientia Iesu Filii Sirach ${ }^{3}$ 2016; Sapientia Salomonis ${ }^{3}$ 2017; Maccabaeorum II ${ }^{4}$ 2017; Esdrae liber II ${ }^{2} 2017$. 
A new long-term Academy project was established in 2020: "Editio critica maior des griechischen Psalters." This edition of the Greek Psalter is based at the Göttingen Academy of Sciences and Humanities and funded by the governments of Lower Saxony and the Federal Republic of Germany. The research project began on 1 January 2020 and will run for twenty-one years. It is led by Reinhard Gregor Kratz (Projektleitung) and Felix Albrecht (Arbeitsstellenleitung).

The new project on the Psalter relates to the most widespread, complex, and extensively interpreted book in the Bible. As a liturgical prayer and individual meditation book, it combines Judaism with Western and Orthodox Christianity. Its influence on poetry (e.g., Arnold Schönberg, Moderne Psalmen; Paul Celan, Tenebrae), music (e.g., Igor Stravinsky, Symphony of Psalms; Leonard Bernstein, Chichester Psalms), and visual arts (e.g., Marc Chagall, Psalms of David) reaches to the present day and makes it one of the fundamental texts of European culture, and world literature as well.

The fact that the Göttingen Academy of Sciences and Humanities houses another long-term project, which deals with the edition of the Coptic-Sahidic daughter version of the Greek Old Testament ("Digital Edition of the Coptic Old Testament," directed by Heike Behlmer and Frank Feder), makes Göttingen a central research location when it comes to the edition and research of the Septuagint. The establishment of these editorial projects under the same roof also enables unique synergic effects in the daily work on the Greek Bible texts of the Old Testament.

The aim of the new Psalter project is to explore the tradition and textual history of the Greek Psalter, and to prepare a new critical edition of the Septuagint Psalms and Odes for the Göttingen series that will replace the outdated edition by Alfred Rahlfs (1931). Although Rahlfs' edition of the Psalter can be seen as either preliminary or rather inadequate, especially regarding the integration of the Hexaplaric tradition (see below, §3.2), it is unquestionable that his editorial work influenced decisively the further course of any text-critical work on the Greek Psalter. The aim of a new edition will be the same as for Rahlfs, that of the text-critical reconstruction of the pre-recensional, oldest attainable Greek text. ${ }^{10}$ When completed, the critically reconstructed text will be provided in a hybrid edition, as a book and online.

10 On this editorial principle, see Bernhard Neuschäfer, "Die kritische Edition des griechischen Alten Testaments. Anspruch und Aufgabe des Göttinger Septuaginta-Unternehmens," in Jahrbuch der Akademie der Wissenschaften zu Göttingen 2004 (Göttingen: Vandenhoeck \& Ruprecht, 2004), 129-139; idem, "Die Göttinger Septuaginta-Ausgabe. Stand- 
In the following, I would like to discuss the planned editorial work by illustrating some of the challenges caused by the extremely complex textual history. Therefore, I would like to use Psalm 1 as a test case and focus on two aspects: (1) As a first step, I would like to provide a brief overview of the editorial history of the Greek Psalter, focusing on the earliest printed versions. This overview will show the major influence of the Lucianic recension on the whole tradition. This influence serves as one of the main challenges and can be seen from the early printed editions (several incunabula, Aldina, Complutensis), while the Sixtine edition marks a turning point, followed by all other modern editions. The editorial procedure for the new Psalter project will be to detect the textual evidence of the Lucianic recension and to determine the degree of its influence, in order to recover the pre-recensional text form, i.e., the oldest reachable pre-Antiochene text; (2) In the second stage, I would like to draw attention to one of the most urgent research tasks, namely the reconstruction of the fragmentary Hexaplaric tradition, reflected by, for example, mss Ra 113 and Ra 271. In the case of the Hexaplaric remains, the editorial procedure is similar: First of all, the Origenic text must be identified in order to determine its recensional elements and to reach the oldest attainable pre-Hexaplaric Psalter text.

\section{1}

The History of Printed Greek Psalteria

The Septuagint Psalter-the most important book in the Greek Old Testament-has a long editorial history, which in turn is closely interwoven with the history of book printing. So, it is hardly surprising that the earliest printings of the Greek Bible in Renaissance Italy were printed editions of the Septuagint Psalter.

\subsubsection{Early Incunabula, Aldina, Complutensis}

Three significant incunabula, containing the $15^{1}$ psalms and the nine odes, emerged in the late fifteenth century:

1. In 1481, a Greek-Latin Psalter, edited by Johannes Crastonus in Milan (incunable $\left.\mathrm{M}_{3} 6246\right) ;{ }^{11}$

ortbestimmung eines editorischen Jahrhundertprojekts. Internationale Fachtagung, Göttingen, 28.-30. April 2008," editio 22 (2008): 241-245; Felix Albrecht, "Die alexandrinische Bibelübersetzung. Einsichten zur Entstehungs-, Überlieferungs- und Wirkungsgeschichte der Septuaginta," in Tobias Georges, Felix Albrecht, and Reinhard Feldmeier, Alexandria, Civitatum Orbis MEditerranei Studia 1 (Tübingen: Mohr Siebeck, 2013), 209-243, here: 220.

11 Cf. Thomas H. Darlow and Horace F. Moule, Historical Catalogue of the Printed Editions of the Holy Scripture in the Library of the British and Foreign Bible Society, 2 vols. (London: The 
2. In 1486, a Greek Psalter, printed by Alexandros of Crete in Venice (incunable $\left.\mathrm{M}_{3} 6247\right) ; 12$

3. In 1497, a Greek Psalter edited by Justinos Dekadyos and printed by Aldus Manutius in Venice (incunable $\left.\mathrm{M}_{3} 6248\right) .{ }^{13}$

I would like to take a closer look at the textual character of these three incunabula to find out which textual tradition they follow. A look at the variants for Psalm 1 is illuminating (text compared to Rahlfs' edition of 1931; see below §3.1.3):

Ad 1) Variants for Psalm 1 in $\mathrm{M}_{3} 6246$ (Greek / Latin):

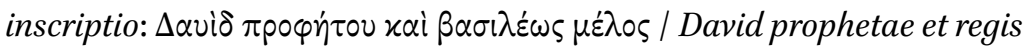
melos.

1:1a-b duo stichi] unus stichus $\mathrm{M}_{36246}$

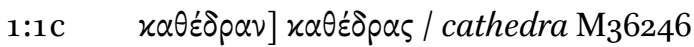

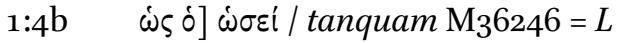

1:5a $\quad \alpha \sigma \varepsilon \beta \varepsilon i \varsigma]$ pr. oi M36246 = B S and some $L$-Mss

Psalm 2 follows with the superscriptio: $\alpha v \varepsilon \pi i \gamma p \alpha \varphi \circ \varsigma \pi \alpha \rho^{\prime} \varepsilon \beta p \alpha i o s$ / sine titulo apud hebraeos.

Ad 2) Variants for Psalm 1 in $\mathrm{M}_{36247}$

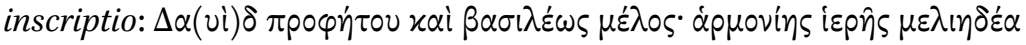
$\alpha \sigma^{\prime} \mu \alpha \tau \alpha \alpha(v i) \delta$.

superscriptio: $\alpha^{\prime}$

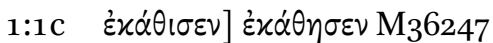

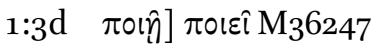

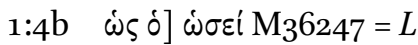

Psalm 2 follows with the superscriptio: $\psi \alpha \lambda \mu$ ò $\tau \hat{\omega} \Delta \alpha(\nu i) \delta \beta^{\prime}$.

Ad 3) Variants for Psalm 1 in $\mathrm{M}_{36248:}$

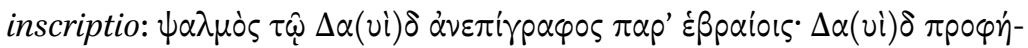

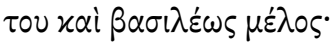

superscriptio: $\alpha^{\prime}$

Bible House, 1903-1911), here: II.2, No 4590 . In this edition, stichoi are separated by dots. The manuscript base for this edition is not clear; Cornelia Linde, "Johannes Crastonus's Edition of the Psalms," The Library VII.13 (2012): 147-163, however, states that the "Greek text is almost identical to Rahlfs' critical edition of the Septuagint" (155); however, that statement is not precise enough.

12 In this edition, stichoi are separated by red dots.

13 Keetje Rozemond, "Het Psalterion van Aldus Manutius," Het Boek 36 (1963-1964): 94-99, supposes that this book was already printed in 1495. In this edition, stichoi are separated from each other by high points; some of the first letters of the individual stichoi are rubricated. 


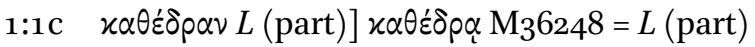

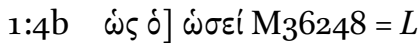

$$
\begin{aligned}
& \text { Psalm } 2 \text { follows with the superscriptio: } \psi \alpha \lambda \mu \text { ò } \tau \hat{\omega} \Delta \alpha(\nu i) \delta \beta^{\prime} \text {. }
\end{aligned}
$$

A first look at these three incunabula shows that they follow a clear textual tradition. Ps 1:4b indicates that all three witnesses can be attributed to the Lucianic tradition, since the varia lectio $\dot{\omega} \sigma \varepsilon i$ for $\dot{\omega} \varsigma \dot{o}$ is clearly Lucianic. This result is hardly surprising, because the manuscript tradition of Septuagint Psalms is strongly influenced by the Lucianic recension. ${ }^{14}$ This applies in particular to the later Byzantine tradition. The fifteenth-century incunabula are clearly standing in the tradition of their time.

In the case of the other early printed editions - some of which are significant in the other books of the Septuagint - the situation is very similar: The Psalter text of the Aldina (1518) is based on the incunable $\mathrm{M}_{3} 6248$, offering a Lucianic text. That means that all the editions that are based on the Aldina also have a Lucianic text. To give one example: The reformer Johannes Draconites (1494-1566) published polyglot editions (Hebrew, Greek, Latin, German) of several Old Testament books. ${ }^{15}$ His incomplete Psalter edition, ${ }^{16}$ which appeared in Wittenberg with the printer Johannes Crato (Johann Krafft the Elder) in 1563, follows the Aldina.

As we have seen, the Greek Psalter belongs to the earliest printed portions of the Greek Bible. Therefore the first printed polyglot Bible text was a Psalter polyglot, edited by Agostino Giustiniani (1470-1536) and published in Genoa in $1516 .{ }^{17}$ The Greek text is based on the Aldine Psalter $\left(\mathrm{M}_{3} 6248\right)$. Subsequently, many polyglot Psalters were published whose Greek Psalter text is always based (directly or indirectly) on the Aldine Psalter, e.g., the Psalter printed in 1516 by Johann Froben in Basel as an appendix to vol. 8 of St. Jerome's works; ${ }^{18}$ and that

14 On the Lucianic recension, its historical background and characteristics, see Felix Albrecht, "Von der hebraica veritas zur vera graecitas: Origenes-Hesych-Lukian," BN 184 (2020): 105-141, here: 113-132.

15 Cf. Darlow and Moule, Catalogue, II.1, No 1420; II.2, No 4628.

16 VD16 B 3402 (http://gateway-bayern.de/VD16+B+3402).

17 Permalink: http://mdz-nbn-resolving.de/urn:nbn:de:bvb:12-bsb11203025-6. Cf. Darlow and Moule, Catalogue, II.1, No 1411. The idea of a polyglot Bible is, however, much older and goes back to Aldus Manutius, who had announced a forthcoming polyglot Bible, which was never completed, in the preface to his Greek Psalter edition. Only a specimen leaf, containing Gen 1:1-15 (Hebrew, Greek, Latin), was printed. Two copies are held by the BnF, Cod. Paris. gr. 3064, f. 86 and f. 87, accessible via Gallica, Permalink: https://gallica.bnf.fr/ark:/12148/btvıb8595102h/fi77.item (f. 86) and https://gallica.bnf.fr/ ark:/12148/btvib8595102h/fi79.item (f. 87).

18 Permalink: http://mdz-nbn-resolving.de/urn:nbn:de:bvb:12-bsb1o934798-o; vD16 н 3482 
printed in 1518 by Johann Potken in Cologne (probably based on the Froben Psalter) ${ }^{19}$ All these editions provide a Lucianic text.

A similar situation obtains with regard to the Complutensis (1520), which is the first complete printed polyglot Bible. The main editor of the Septuagint for the Complutensis seems to have been Dimitrios Doukas the Cretan (ca. 148o1527), the chair of Greek at Alcalá, who had worked before for Aldus Manutius in Venice. ${ }^{20}$ The text of the Old Testament is printed in three columns per page. For the Psalter, which is printed without Psalm 151 and without Odes, the outer column has the Hebrew Masoretic Text, the small middle column presents Jerome's Psalterium iuxta Hebraeos, and the inner column has the Greek Septuagint with Latin Vulgate as interlinear translation. Fernández Marcos, following Franz Delitzsch, has shown that the Psalter text of the Complutensis is based

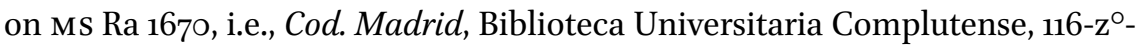
30 (olim Villa-Amil 23, olim E.1.30; 14th/15th c.). ${ }^{21}$ The following variants are to be noted for Psalm 1 (text compared to Rahlfs' edition of 1931; see below $§ 3.1 .3$ ):

(http://gateway-bayern.de/VD16+H+3482). Several reprints, cf. Darlow and Moule, Catalogue, II.1, 6.

19 Permalink: http://data.onb.ac.at/rep/102AE98E; Darlow and Moule, Catalogue, II.1, No 1413; II.2, No 4595. VD16 B 3101 (http://gateway-bayern.de/VD16+B+3101).

20 Cf. Marcel Bataillon, Érasme et l'Espagne. Recherches sur l'histoire spirituelle du Xvie siècle (Paris: Droz, 1937), 42; Deno John Geanakoplos, Greek Scholars in Venice. Studies in the Dissemination of Greek Learning from Byzantium to Western Europe (Cambridge: Harvard University Press, 1962), 239 n. 70; Ángel Sáenz-Badillos, La filología bíblica en los primeros helenistas de Alcalá, Institución San Jerónimo 18 (Estella [Navarra]: Ed. Verbo Divino, 1990), 399; John A.L. Lee, "Dimitrios Doukas and the Accentuation of the New Testament Text of the Complutensian Polyglot," NT 47 (2005): 250-29o, here: 29o n. 55; Scott Mandelbrote, "The Old Testament and its Ancient Versions in Manuscript and Print in the West, from c. 1480 to c. 1780," in vol. 3 of The New Cambridge History of the Bible, ed. E. Cameron (Cambridge: Cambridge University Press, 2016), 82-109, here: 97; Alastair Hamilton, "In Search of the Most Perfect Text. The Early Modern Printed Polyglot Bibles from Alcalá (1510-1520) to Brian Walton (1654-1658)," in vol. 3 of The New Cambridge History of the Bible, ed. E. Cameron (Cambridge: Cambridge University Press, 2016), 138-156, here: 141; Luis Gil Fernández, "La columna griega de la Biblia Poliglota Complutense," in La Biblia políglota complutense en su contexto, ed. Antonio Alvar Ezquerra (Alcalá de Henares: Universidad de Alcalá, Servicio de Publicaciones, 2016), 261-283, here: 278. On Dimitrios Doukas, see Geanakoplos, Scholars, 223-255; Sáenz-Badillos, Filología, 398-399.

21 Cf. Natalio Fernández Marcos, "El texto griego de Septuaginta en la Políglota Complutense," EstBib 72 (2014): 103-117, 110; Franz Delitzsch, Fortgesetzte Studien zur Entstehungsgeschichte der complutensischen Polyglotte (Leipzig: Edelmann, 1886), 28-29. On this manuscript, see Alfred Rahlfs, Verzeichnis der griechischen Handschriften des Alten Testaments. Für das Septuaginta-Unternehmen aufgestellt, MsU 2 (Berlin: Weidmannsche Buchhandlung, 1914), 124, and Pinakes (https://pinakes.irht.cnrs.fr), Numéro diktyon: 40407. Nowa- 


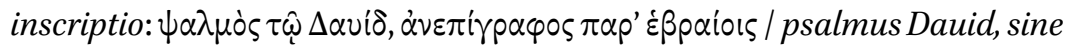
titulo apud hebreos. superscriptio: $\alpha^{\prime} / 1$. 1:4b ís ó $\dot{\omega}^{\prime} \sigma \varepsilon^{\prime} /$ tanquam Compl $=L$

Psalm 2 follows with the superscriptio: $\psi \alpha \lambda \mu$ ò $\tau \hat{\omega} \Delta \alpha(\nu i) \delta \beta^{\prime}$ / psalmus Dauid 2.

Standing in the tradition of the Complutensis, several other polyglot Bibles emerged: In Antwerp, for instance, a polyglot Bible was prepared by Benito Arias Montano (1527-1598) and printed by Christopher Plantin (1520-1589), the so-called Plantin or Antwerp Polyglot, Biblia Regia or Plantiniana (15691573) in eight volumes (vol. 3 Psalter), whose Septuagint text is based on the Complutensis. ${ }^{22}$ An adaptation of the Antwerp Polyglot is the Paris Polyglot (1628-1645), printed by Antoine Vitré in nine volumes. Concerning the Septuagint, the arrangement and text follow the Antwerp Polyglot, i.e., the text is that of the Complutensis, ${ }^{23}$ and therefore belongs to the Lucianic text-type.

days, MS Ra 1670 is defective at the beginning, i.e., one leaf (fol. 1 , containing Ps 1:1-5) is missing.

Benito Arias Montano, ed., Biblia Sacra Hebraice, Chaldaice, Graece, et Latine. Philippi II. Reg. Cathol. pietate et studio ad sacrosanctae ecclesiae usum, 8 vols. ([Antwerp:] ex Officina Plantiniana, 1569-1573). Cf. Darlow and Moule, Catalogue, II.1, No 1422; II.2, No 4637; Antonella Lumini, La Bibbia. Edizioni del xvi secolo, Biblioteca di bibliografia italiana 162 (Florence: Olschki, 200o), № 2; Theodor William Dunkelgrün, "The Multiplicity of Scripture. The Confluence of Textual Traditions in the Making of the Antwerp Polyglot Bible (1568-1573)" (PhD diss., The University of Chicago, 2012); Adrian Schenker, "The Polyglot Bibles of Antwerp, Paris and London: 1568-1658," in vol. II of Hebrew Bible, Old Testament. The History of Its Interpretation, ed. Magne Sæbø et al. (Göttingen: Vandenhoeck \& Ruprecht, 2008), 774-784, here: 775-779; idem, "Der alttestamentliche Text in den vier großen Polyglottenbibeln nach dem heutigen Stand der Forschung," TRev 90 (1994): 177188, here: 181-183; Hamilton, "Search," 143-147; Eveline van Staalduine-Sulman, Justifying Christian Aramaism. Editions and Latin Translations of the Targums from the Complutensian to the London Polyglot Bible (1517-1657), Jewish and Christian Perspectives Series 33 (Leiden: Brill, 2017), 110-159; furthermore Mandelbrote, "Old Testament," 100-101. According to Hamilton, "Search," 145, "The Septuagint was emended (but not always improved) from the Aldine edition."

23 Cf. Darlow and Moule, Catalogue, II.1, № 1442; II.2, № 4688; Schenker, "Polyglot Bibles," 779-781; idem, "Text," 183-185; Peter N. Miller, "Making the Paris Polyglot Bible. Humanism and Orientalism in the Early Seventeenth Century," in Die europäische Gelehrtenrepublik im Zeitalter des Konfessionalismus. The European Republic of Letters in the Age of Confessionalism, ed. Herbert Jaumann, Wolfenbütteler Forschungen 96 (Wiesbaden: Harrassowitz, 2001), 59-85; Hamilton, "Search," 148-151; van Staalduine-Sulman, Justifying, 191-198. 
A new development took place after the appearance of the Sixtina (1586/1587; in 1588 , a Latin translation was published). ${ }^{24}$ The plans for a new edition of the Greek Bible were made during the Council of Trent (1545-1563), and the work began under Pope Gregory XIII in 1578, directed by Cardinal Antonio Carafa (1538-1591). The edition was finally printed in 1586, but received papal imprimatur by Pope Sixtus v in 1587; so the printing date was corrected by hand in 1587.25 The Sixtine edition was reprinted several times; a famous reprint that combined the edition from 1587 with the Latin translation from 1588 was published in Paris in 1628. It became the authoritative edition and provided the base text for biblical scholarship over centuries. ${ }^{26}$

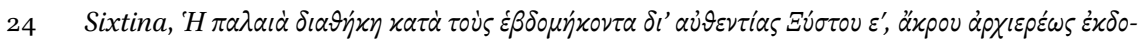
$\vartheta \varepsilon i \sigma \alpha$.Vetus Testamentum iuxta Septuaginta ex auctoritate Sixti v. pont. max. editum (Rome: ex typographia Francisci Zanetti, 1587). Darlow and Moule, Catalogue, II.2, No 4647 .

25 On the history of the Sixtina, see Eberhard Nestle, Septuagintastudien [I], Programm des Kgl. Gymnasiums in Ulm 547 (Ulm: Wagnersche Buchdruckerei, 1886); furthermore, Henry Barclay Swete, An Introduction to the Old Testament in Greek. Revised by R.R. Ottley, With an Appendix Containing the Letter of Aristeas Edited by H.J. Thackeray (Cambridge: Cambridge University Press, 1914), 174-182; Giancarlo Pani, "L'edizione Sistina dei Settanta. Quattro secoli dopo," SMSR 54 (1988): 371-389; idem, "Un centenaire à rappeler. L'édition Sixtine des Septante," in Théorie et pratique de l'exégèse, ed. Irena Backus and Francis Higman (Geneva: Libraire Droz S.A., 199o); Scott Mandelbrote, "When Manuscripts Meet. Editing the Bible in Greek during and after the Council of Trent," in vol. 1 of For the Sake of Learning. Essays in Honor of Anthony Grafton, ed. Ann Blair and Anja-Silvia Goeing, Scientific and Learned Cultures and their Institutions 18/1 (Leiden: Brill, 2016), 251-267, here: 255258 .

26 Cf. Darlow and Moule, Catalogue, II.2, No $4674-4675$; reprinted in 1641. This edition in three volumes was published by several printers, inter alia by Sébastien Chappelet, etc., in 1628:

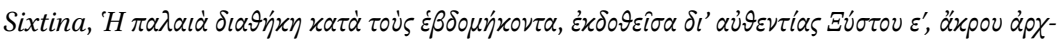

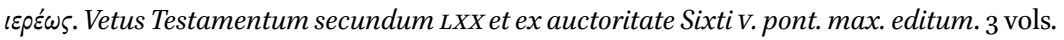
(Paris: apud Sebastianum Chappelet, 1628); cf. also the Leipzig edition printed by Johann

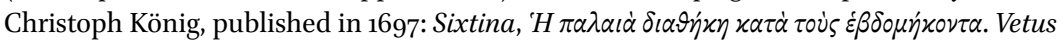
Testamentum Graecum ex versione Septuaginta interpretum [...] (Leipzig: sumptibus Joh. Christophori Konigii, 1697). Another edition based on the Sixtina is J.G. Kirchner's Septuagint in four volumes, published in 1759-176o in Halle (vD18 11136154; fifth volume with apocrypha, 1766); cf. Darlow and Moule, Catalogue, II.2, 630. The Paris edition from 1628 was also used as the base text for the famous London Polyglot, which was published by Brian Walton (160o-1661) in 1653-1657; on the London Polyglot, see Darlow and Moule, Catalogue, II.1, No 1446; II.2, No 4696. Cf. Adam Clarke, A Succinct Account of Polyglott Bibles. From the Publication of that by Porrus, in the Year 1516, to that of Reineccius, in 1750. Including Several Curious Particulars Relative to the London Polyglott, and Castel's Heptaglott Lexicon, Not Noticed by Bibliographers (Liverpool: J. Nuttall, 1802); Henry John Todd, Memoirs of the Life and Writings of the Right Rev. Brian Walton, D.D. Lord Bishop of Chester, Editor of the London Polyglot Bible [...]. 2 vols. (London: Printed for F.C. \& J. Rivington, 
In general, the Sixtina provides a Septuagint text, which is based mainly on Codex Vaticanus (B) and the Aldina. ${ }^{27}$ The Sixtine Psalter text is not written in stichoi, but the punctuation reveals the stichometric structure in the background. Regarding the textual character of the Sixtina, the dependence on Codex B is unmistakable. In addition, the Sixtina offers a major innovation that enhances it enormously compared to the previous editions: The critical apparatus of the Sixtina, prepared for the first edition of $1586 / 1587$ by Pierre Morin (Petrus Morinus) and augmented for the Latin edition of 1588 by Flaminio de Nobili (Flaminius Nobilius), ${ }^{28}$ provides rich Hexaplaric material that, at least in the case of the information on Ps 1:1a and 1:1c, derives from Ms Ra 1175 (Cod. Vat. gr. 754). ${ }^{29}$ Ms Ra 1175 is a witness of the Palestinian catena of Psalms that belongs to catena type XIII (Karo-Lietzmann) and has many Hexaplaric readings. These readings derived-according to Gilles Dorival-from a common collection of Hexaplaric readings, which were added secondarily to an original catena type without such readings. ${ }^{30}$ Ekkehard Mühlenberg suggests an

1821), esp. I:31-88; Judy A. Knop, The Editing and Publishing of the London Polyglot, 16541657 (Diss., The University of Chicago, 1977); Peter N. Miller, “The 'Antiquarianization' of Biblical Scholarship and the London Polyglot Bible (1653-1657)," JHI 62 (2001): 463-482; Schenker, "Text," 185-188; idem, "Polyglot Bibles," 781-784; Scott Mandelbrote, "English Scholarship and the Greek Text of the Old Testament, 1620-1720. The Impact of Codex Alexandrinus," in Scripture and Scholarship in Early Modern England, ed. Ariel Hessayon and Nicholas Keene (Aldershot: Ashgate, 2006), 74-93, here: 85-87; Hamilton, "Search," 151-154; van Staalduine-Sulman, Justifying, 199-229.

27 For Sixtina's dependence on the Aldina, cf. Alfred Rahlfs, "Die Abhängigkeit der sixtinischen Septuaginta-Ausgabe von der aldinischen," ZAW 33 (1913): 30-46. In addition, Cod. Venetus "V" (cf. Pierre Batiffol, La Vaticane de Paul III à Paul V, d'après des documents nouveaux, Petite bibliothèque d' art et d' archéologie [Paris: Leroux, 189o], 90-91) and the Complutensis via Antwerp Polyglot (cf. F. Amann, "Die römische Septuagintarevision im 16. Jahrhundert," $B Z 12$ [1914]: 116-124) have also been used.

28 Cf. Timothy Michael Law, "A History of Research on Origen's Hexapla. From Masius to the Hexapla Project," вIOscs 40 (2007): 30-48, here: 32-34.

29 Already Otto Procksch, "Tetraplarische Studien," ZAW 12 (1935): 240-269, here: 257, supposed that Mss Ra 1175 and Ra 264 (see below) were the Hexaplaric sources for the Sixtina. Cod. Vat. gr. 754 (Ra 1175) is available online (https://digi.vatlib.it/view/MSS_Vat.gr.754). On this manuscript, see Rahlfs, Verzeichnis, 256, and Pinakes (https://pinakes.irht.cnrs .fr), Numéro diktyon: 67385 . Nobilius only gave a selection of Hexaplaric readings from MS Ra 1175. The manuscript contains more material that was edited by Jean-Baptiste Pitra, Analecta sacra Spicilegio Solesmensi parata. Vol. 3, Patres antenicaeni (Venice: e typographeo Veneto Mechitaristarum Sancti Lazari, 1883), 557-56o.

30 Cf. Gilles Dorival, Les chaînes exégétiques grecques sur les Psaumes. Tome 2, ssL 44 (Leuven: Peeters, 1989), 346-347. Also Adrian Schenker, Psalmen in den Hexapla. Erste kritische und vollständige Ausgabe der hexaplarischen Fragmente auf dem Rande der Handschrift Ottobonianus graecus 398 zu den Ps 24-32, StT 295 (Vatican City: Biblioteca Apostolica Vat- 
Athanasius manuscript as its source. ${ }^{31}$ The second source for Morinus (and Nobilius) seems to have been Ms Ra 264 (Cod. Ottob. gr. 398). ${ }^{32}$

\subsubsection{From Early Modern Editions to Alfred Rahlfs (1931)}

Another turning point in the history of the Septuagint editions was the appearance of Codex Alexandrinus (A) in the Western world. The study of Codex A began soon after the manuscript came to England in 1628. Consequently, new editions of the Psalter appeared that took Codex A into account: In 1678, Thomas Gale (1635-1702), Regius Professor of Greek at Cambridge from 1666, published such an edition of the Psalter without critical apparatus, containing 150 psalms and Ode 14. ${ }^{33}$ In 1709, the fourth volume of Johann Ernst Grabe's (1666-1711) edition of the Septuagint containing the Psalms was printed. ${ }^{34}$

In 1788 , a project directed by Robert Holmes (1748-1805) began at Oxford University, in order to prepare a new large edition of the Septuagint (five volumes; published 1798-1827). ${ }^{35}$ The 151 psalms (without odes) appeared as a part of volume 3, published by Jacob Parsons after Holmes' death in 1823. It reprints the Sixtina as a base text, and the apparatus provides variant readings based on eclectic collations of many manuscripts, while an appendix contains Hexaplaric readings. The edition by Holmes and Parsons was the most impor-

icana, 1982), 26-27, argues for a certain collection of Hexaplaric readings as a source for manuscripts like Ra 1173 (Cod. Vat. gr. 752), Ra 1175 (Cod. Vat. gr. 754), and Ra 264 (Cod. Ottob. gr. 398).

31 Cf. Ekkehard Mühlenberg, Psalmenkommentare aus der Katenenüberlieferung. Vol. 3, Untersuchungen zu den Psalmenkatenen, PTS 19 (Berlin: De Gruyter, 1978), 30-31.

32 Cf. Procksch, "Studien [I]," 257. Schenker, Psalmen, (re)edited the Hexaplaric readings of Ms Ra 264, a manuscript that was used by Field on the basis of collations that were made by Elia Baldi for the edition of Holmes and Parsons, and which were not sufficiently accurate. Cf. Schenker, Psalmen, 23-25 ("Sinn und Notwendigkeit einer Ausgabe der hexaplarischen Psalmenfragmente der Hs Ottobonianus graecus $\left.398^{\prime \prime}\right)$.

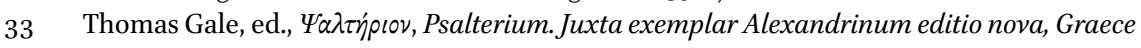
et latine (Oxford: e Theatro Sheldoniano, 1678).

34 Johannes Ernst Grabe, Vetus Testamentum ex versione Septuaginta interpretum. Vol. 4 (Oxford: e Theatro Sheldoniano, 1709). (Published in four volumes: cf. Darlow and Moule, Catalogue, II.2, $\mathrm{N}^{\circ}$ 4733; another edition appeared as eight volumes: cf. Darlow and Moule, Catalogue, II.2, No 4734). On Grabe, see Günther Thomann, "John Ernest Grabe (1666-1711). Lutheran Syncretist and Anglican Patristic Scholar," JEH 43 (1992): 414-427; on his edition, see Swete, Introduction, 182-184; Mandelbrote, "Scholarship," 89-92.

35 Cf. Rahlfs, Verzeichnis, vii-viii, n. 1, and Robert Holmes, The First Annual Account of the Collation of the Mss. of the Septuagint Version. To Which is Prefixed a Tract (Oxford: Clarendon, 1789). From 1789 to 1805, seventeen "Annual Accounts of the Collation" appeared, and a further five "Annual Accounts of the Publication" between 1801 and 1805. On the great Oxford edition, see Swete, Introduction, 184-187. 
tant edition of Psalms for more than a century, up to the appearance of Rahlfs' edition in 1931 (see below). In the meantime, however, additional editions were published: ${ }^{36}$ for instance, the small edition in three volumes by Henry Barclay Swete (1835-1917) that contains Psalms (vol. 2, 1891; ${ }^{3} 1907$ ) and Odes (vol. 3, 1894; $\left.{ }^{4} 1912\right) \cdot{ }^{37}$

A new era of editorial work, however, began with Paul Anton de Lagarde (1827-1891). In the 188os, de Lagarde prepared two different editions of the Greek Psalter: ${ }^{38}$ an editio critica "maxima" extended as far as Psalm 5 and was published in $1887^{39}$ an editio critica maior was finished up to Psalm 48, when de Lagarde died in 1891. Alfred Rahlfs $\left(1865^{-1935)^{40}}\right.$ continued his teacher's work: He finished the edition up to LXx Psalm 49 and published it in 1892. ${ }^{41}$ In the following years, Rahlfs continued to work on the Psalter and, in 1907, he published an important monograph on the text history of Psalms, Der Text

36 Cf., e.g., Eberhard Nestle and Samuel Gideon Frederic Perry, eds., Psalterium tetraglottum. Graece, Syriace, Chaldaice, Latine [...] (Tübingen: Fr. Fues et al., 1879) (without critical apparatus); Konstantin von Tischendorf and Eberhard Nestle, eds., 'H $\pi \alpha \lambda \alpha i \dot{\alpha} \delta ı \alpha-$

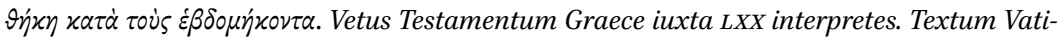
canum Romanum emendatius edidit, argumenta et locos Novi Testamenti parallelos notavit, omnem lectionis varietatem codicum vetustissimorum Alexandrini, Ephraemi Syri, FridericoAugustani subiunxit, Prolegomenis uberrimis instruxit Constantinus de Tischendorf. Editio septima, Prolegomena recognovit Supplementum auxit Eberardus Nestle. 2 vols., 7 th ed. (Leipzig: Brockhaus, 1887), here: 37-112 (without Odes).

37 Henry Barclay Swete, ed., The Old Testament in Greek according to the Septuagint, Vol. 2: IChronicles-Tobit, 3rd ed. (Cambridge: Cambridge University Press, 1907); idem, The Old Testament in Greek according to the Septuagint, Vol. 3: Hosea-4Maccabees, Psalms of Solomon, Enoch, the Odes, 4th ed. (Cambridge: Cambridge University Press, 1912).

38 Cf. Christian Schäfer, Alfred Rahlfs (1865-1935) und die kritische Edition der Septuaginta. Eine biographisch-wissenschaftsgeschichtliche Studie, BZAW 489 (Berlin: De Gruyter, 2016), 135 with n. 7 o.

39 Paul Anton de Lagarde, Novae Psalteriigraecieditionis specimen, Abhandlungen der Königlichen Gesellschaft der Wissenschaften zu Göttingen 33 (Göttingen: Dieterichsche Verlags-Buchhandlung, 1887); cf. Alfred Rahlfs, Paul de Lagardes wissenschaftliches Lebenswerk im Rahmen einer Geschichte seines Lebens dargestellt, MSU 4.1 (Berlin: Weidmann, 1928), 8o-81, who described this edition as "grotesquely gigantic"; Bernhard Neuschäfer, "Alteri saeculo. Paul Anton de Lagardes 'Lebensarbeit' an der Septuaginta," in Die Göttinger Septuaginta. Ein editorisches Jahrhundertprojekt, ed. Reinhard G. Kratz and Bernhard Neuschäfer, AAWG NF 22; MSU 30 (Berlin: De Gruyter, 2013), 235-264, here: 250-251 with nn. 58, 6o-61.

40 On Rahlfs, see Schäfer, Rahlfs.

41 Alfred Rahlfs, ed., Psalterii graeci quinquagena prima a Paulo de Lagarde in usum scholarum edita (Göttingen: prostat in aedibus Dieterichianis Luederi Horstmann, 1892); cf. Rahlfs, Lebenswerk, 81-82; Neuschäfer, "Alteri saeculo," 251 with n. 63; Schäfer, Rahlfs, 6o61. 
des Septuaginta-Psalters ${ }^{42}$ which gave a detailed analysis of the Psalter tradition and its textual history. In 1908, as the first "Arbeitsstellenleiter" of the Septuaginta-Unternehmen, Rahlfs inevitably turned to other tasks and only later found his way back to the Psalter. In 1931, he finally published his edition of Psalmi cum Odis. ${ }^{43}$ It was printed as vol. $\mathrm{x}$ of a new series, since 1931 published by Vandenhoeck \& Ruprecht in Göttingen, which was planned by Rahlfs as a "major edition of the Septuagint," and which soon became the leading standard. The Psalter edition by Rahlfs was a milestone in Septuagint scholarship, since it was the first edition of the new Göttingen series and the beginning of a new kind of Septuagint edition that presents an eclectic critical text based on new collations. A major desideratum of Rahlfs' Psalter edition is, however, the lack of attention to the Hexaplaric Psalter tradition.

\subsection{The Reconstruction of the Fragmentary Hexaplaric Tradition}

Interest in the Hexaplaric tradition of the Psalter goes back to the sixteenth century: In 1581, Johannes van den Driesche (Drusius, 1550-1616) published some of its fragments. ${ }^{44}$ Drusius' edition seems to have been unknown to the Sixtine editors, namely Morinus and Nobilius (see above). ${ }^{45}$ A major improvement was the edition by Bernard de Montfaucon (1655-1741), printed in $1713^{46}$ The following research depended essentially on him: e.g., Karl Friedrich Bahrdt (1740-1792), and Ernst Gottfried Adolf Böckel (1783-1854), who prepared an edition of LXX Psalms 1-3 with two apparatus (the first for variant readings and comparison with MT, etc.; the second for Hexaplaric material) that was published in $1820 .{ }^{47}$ In the same year (1820), an edition of the Psalms according

42 Alfred Rahlfs, Der Text des Septuaginta-Psalters. Nebst einem Anhang, Griechische Psalterfragmente aus Oberägypten nach Abschriften von W.E. Crum, Septuaginta-Studien 2 (Göttingen: Vandenhoeck \& Ruprecht, 1907).

43 Alfred Rahlfs, ed., Psalmi cum Odis, 3rd ed., Septuaginta. Vetus Testamentum Graecum auctoritate Academiae Litterarum Gottingensis editum X (Göttingen: Vandenhoeck \& Ruprecht, 1979). The Psalter was, of course, also included into Rahlfs' "Handausgabe" (1935/2006): vol. II, 1-183.

44 Johannes Drusius, ed., In Psalmos Davidis veterum interpretum quae exstant fragmenta (Antwerp: ex officina Christophori Plantini, 1581).

45 Cf. Law, "History," 35.

46 Bernard de Montfaucon, Hexaplorum Origenis quae supersunt, multis partibus auctiora, quam a Flaminio Nobilio \& Joanne Drusio edita fuerint [...] (Paris: apud Ludovicum Guerin, viduam Joannis Boudot, et Carolum Robustel, 1713). Cf. Darlow and Moule, Catalogue, II.2, No 4729a. Reprinted in Jacques-Paul Migne's Patrologia Graeca, vols. 15-16.

47 Karl Friedrich Bahrdt, Hexaplorum Origenis quae supersunt auctiora et emendatiora, quam a Flaminio Nobilio, Ioanne Drusio et tandem a Bernardo de Montfaucon concinnata fuerant [...] (Leipzig: Christian Gottfried Donatius, 1769-1770) [vD18 1107549X-oo1]; Ernst Gott- 
to the famous Syro-Hexapla manuscript from Milan by Gaetano Bugati (17451816) was published posthumously. ${ }^{48}$ All these preparatory works culminated into Frederick Field's (1801-1885) opus magnum that was published in $1875 .{ }^{49}$ Further material was published by Cardinal Jean-Baptiste Pitra. ${ }^{50}$

De Lagarde had used the Hexaplaric material given by Field for his monumental edition of the first five psalms (1887) but did not incorporate this material into his smaller edition that was finished by Rahlfs (1892). Following the example of the latter, Rahlfs took no account of the Hexaplaric material for his 1931 edition. Maybe the discovery of ms Ra 1098 (Cod. Ambros. O 39 sup.) by Giovanni Mercati - announced in 1896, and published in 1958-1965-was another reason for that disregard. ${ }^{51}$ Therefore, a key task in the preparation of the second "Hexaplaric" apparatus for the new Göttingen Psalter edition will be to collect all Hexaplaric fragments. Here, for example, Schenker's work needs to be taken into account. ${ }^{52}$ For the collection of material, some peculiarities

fried Adolf Böckel, Novae clavis in Graecos interpretes Veteris Testamenti scriptoresque apocryphos ita adornatae ut etiam lexici in Novi Foederis libros usum praebere possit atque editionis LXX. interpretum Hexaplaris specimina (Leipzig: Frider. Christ. Guil. Vogel, 1820), $30-36$.

48 Gaetano Bugati, ed., Psalmi secundum editionem LXX interpretum, quos ex codice SyroEstranghelo bibliothecae Ambrosianae Syriace imprimendos curavit, Latine vertit, notisque criticis illustravit (Milan: Jacobus Pirola, 1820).

49 Frederick Field, Origenis Hexaplorum quae supersunt sive veterum interpretum Graecorum in totum Vetus Testamentum fragmenta, 2 vols. (Oxford: Clarendon, 1875). See also idem, Otium Norvicense sive Tentamen de reliquiis Aquilae, Symmachi, Theodotionis e lingua Syriaca in Graecam convertendis (Oxford: Academiae typographi, 1864); idem, Otium Norvicense. Pars altera. Tentamen de quibusdam vocabulis Syro-Graecis in R. Payne Smith S.T.P. Thesauri Syriaci fasciculis I-III reconditis (Oxford: Academiae typographi, 1876). The Psalms are printed in Origenis Hexaplorum fragmenta, II:83-305; further Hexaplaric readings to the Psalms are included in the "Auctarium ad Origenes Hexapla," 11-22, appended to Origenis Hexaplorum fragmenta, vol. II.

50 Pitra, Analecta sacra III, 557-560.

51 Giovanni Mercati, Psalterii hexapli reliquiae. Codex rescriptus Bybliothecae Ambrosianae O 39 Sup., Phototypice expressus et transcriptus. Codices ex ecclesiasticis Italiae Bybliothecis delecti phototypice expressi 8 (Vatican City: Biblioteca Apostolica Vaticana, 1958); idem, Psalterii hexapli reliquiae. Osservazioni, Commento critico al testo dei frammenti esaplari. Codices ex ecclesiasticis Italiae Bybliothecis delecti phototypice expressi 8 (Vatican City: Biblioteca Apostolica Vaticana, 1965). Giovanni Mercati had always a good connection to the Göttinger Septuaginta-Unternehmen. In 1901, he became a corresponding member of the Göttingen Academy; cf. Holger Krahnke, Die Mitglieder der Akademie der Wissenschaften zu Göttingen 1751-2001, AAWG, Philologisch-Historische Klasse III.246 (Göttingen: Vandenhoeck \& Ruprecht, 2001), 166.

52 Adrian Schenker, Hexaplarische Psalmenbruchstücke. Die hexaplarischen Psalmenfragmente der Handschriften Vaticanus graecus 752 und Canonicianus graecus 62, ово 8 (Göttingen: Vandenhoeck \& Ruprecht; Freiburg: Universitätsverlag, 1975); idem, Psalmen. 
specific to the Psalms have to be considered. In the case of the Hexapla of Psalms, there are some differences from most other books that Origen edited for his Hexapla: In the Hexapla of Psalms, Origen used two other versions of the biblical text, called Quinta and Sexta. ${ }^{33}$ The sixth column, which usually offers the text of the Jewish reviser Theodotion, contains the Quinta in the case of the Hexapla of Psalms. Mercati has shown, and Venetz has confirmed, that the material that is assigned by the siglum $\theta^{\prime}$ in the Catena tradition must be attributed to the Quinta; a tradition of Theodotion is, in the case of Psalms, not detectable. ${ }^{54}$ The Mercati Palimpsest (Ra 1098) allows for a more detailed characterization: As shown by Venetz, the Quinta turns out to belong to the xaire-group; the Sexta, on the other hand, shows strong agreement with the Origenic recension. The fifth column, which offers the Origenic recension, contains marginal readings from the Quinta; the sixth column, which offers the Quinta, contains marginal readings from the Sexta.

For the Psalter, we are fortunate to have much material. At least four of the five indirect columnar witnesses to the lost Hexapla of Origen come from the Psalter: The famous Mercati Palimpsest, i.e., Ms Ra 1098 (see above); the Genizah Palimpsest, i.e., MS Ra 2005 (Cambridge, MS T-S 12.182);55 MS Ra 113 and MS Ra 271, described below:

3.2.1 MS Ra 113, fol. $7^{\mathrm{v}}$

Ms Ra 113 (Cod. Ambros. B 106 sup.) provides on fol. $7^{\mathrm{v}}$ a note, which among other things offers the title of the Psalter, in five columns. It was published and commented on by Giovanni Mercati already in $1896 .{ }^{56}$

53 Origen wrote about these two additional versions; cf. Giovanni Mercati, Note di letteratura biblica e cristiana antica, StT 5 (Rome: Tipografia Vaticana, 1901), 28-46, and recently Franz Xaver Risch, "Origenes, De Quinta et Sexta," in Die Prologtexte zu den Psalmen von Origenes und Eusebius, ed. Cordula Bandt et al., TU 183 (Berlin: De Gruyter, 2018), 7175 .

54 Cf. Mercati, Codex, xxv-Xxxi; Hermann-Josef Venetz, Die Quinta des Psalteriums. Ein Beitrag zur Septuaginta- und Hexaplaforschung, Publications de l'Institut de recherche et d'histoire des textes. Collection Massorah I.2 (Hildesheim: Gerstenberg, 1974), 85. This, however, does not seem to be the communis opinio: John D. Meade, "Psalms, §10.3.5 Hexaplaric Greek Translations," THB $1 \mathrm{C}$ (Leiden: Brill, 2017): 98-103, does not address the question of the Quinta in the Psalter.

55 Cf. the edition by Charles Taylor, Hebrew-Greek Cairo Genizah Palimpsests from the TaylorSchechter Collection. Including a Fragment of the Twenty-Second Psalm According to Origen's Hexapla (Cambridge: Cambridge University Press, 190o); the manuscript is accessible online: https://cudl.lib.cam.ac.uk/view/MS-TS-ooo12-0o182.

56 Cf. Giovanni Mercati, "D'un palimpsesto Ambrosiano contenente i Salmi esapli e di un'antica versione latina del commentario perduto di Teodoro di Mopsuestia al Salterio," Atti 


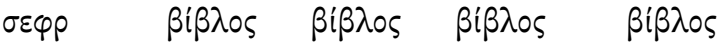 \\ $\alpha \theta \varepsilon \lambda \lambda l \mu^{57} \quad \psi \alpha \lambda \mu \omega \nu$ $\psi \alpha \lambda \mu \omega \hat{\omega} \quad \psi \alpha \lambda \mu \omega \nu^{58} \quad \psi \alpha \lambda \mu \hat{\omega} \nu$}

3.2.2 MS Ra 271, p. II I

Ra 271 (Cod. Vat. gr. 1747$)^{59}$ contains on flyleaf 2 recto (paginated as page "III") three different texts: (1) The beginning of LXX Psalm 1 (Ps 1:1-2a); (2) An overview of the Hebrew alphabet ( $\delta \dot{\alpha} \lambda \varphi \dot{\alpha} \beta \eta \tau \leftarrow \varsigma \tau \omega \nu \dot{\varepsilon} \beta p \alpha i \omega \nu)$, which gives the Greek names of the respective Hebrew letters (often with the Greek letter written above it) and the Hebrew letters; ${ }^{60}$ (3) LXx Ps 111:1a in two columns: The first column should be equated with the Secunda, ${ }^{61}$ the second follows, with some deviations, the text according to the Septuagint (see below). This important flyleaf of Cod. Vat. gr. 1747 was discovered by Giovanni Mercati already in $1899,{ }^{62}$

della R. Accademia delle scienze di Torino 31 (1895-1896): 655-676, here: 664-665 with the edition of that note. On this manuscript, see Rahlfs, Verzeichnis, 126, and Pinakes (https:// pinakes.irht.cnrs.fr), Numéro diktyon: 4235 .

57 Cf. on this reading of the Secunda: Origenes, Catholica in psalmos 1 (Franz Xaver Risch, ed., "Origenes, Catholica in psalmos," in Die Prologtexte zu den Psalmen von Origenes und Eusebius, ed. Cordula Bandt et al., TU 183 [Berlin: De Gruyter, 2018], 3-27, here: 10 [formerly

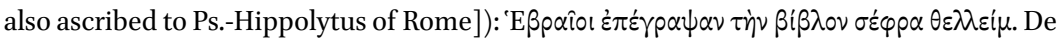
Lagarde, Specimen, 7 , wanted to emend $\sigma \varepsilon \varphi p \alpha \theta \varepsilon \lambda \lambda \varepsilon i \mu$ to $\delta \theta \varepsilon \lambda \lambda \varepsilon i \mu$ : "corrige $\delta \theta \varepsilon \lambda \lambda \varepsilon \mu[. ..] \delta$ post $\alpha$ omitti facile poterat." This emendation is, however, not necessary. Risch, "Catholica," $10, n$. 3, also notes that the anonymous glossator of Ra 113 focused on accuracy by indicating the Hexapla's original line break $\sigma \varepsilon \varphi p \alpha \theta \varepsilon \lambda \lambda \mu$.

58 Mercati, "Palimpsesto," 665 with n. 3, reads $\psi \alpha \lambda \mu \nu 0 \hat{0}$

59 Cod.Vat.gr. 1747 is available online (https://digi.vatlib.it/view/MSS_Vat.gr.1747).

6o A writing exercise (?) of the alphabet on the flyleaf of a manuscript is not uncommon, cf., e.g., Psalter Catena Ra 1104 (Cod. Mosqu. Bibl. Syn. 194), verso of the mutilated flyleaf, which has a Hebrew alphabet (Greek names of the Hebrew letters, and Hebrew letters); Psalter Catena Ra 1140 (Cod. Paris. gr. 164), fol. $6^{\mathrm{v}}$, which has on top Ps 1:1-3a $\alpha$ and underneath the Latin alphabet with the names of the Latin letters in Greek.

61 On the Secunda, see esp. Benjamin Paul Kantor, "The Second Column (Secunda) of Origen's Hexapla in Light of Greek Pronunciation" (PhD diss., The University of Texas at Austin, 2017), who is preparing an edition of the Secunda for the Hexapla project (www .hexapla.org); and furthermore Alexey Eliyahu Yuditsky, A Grammar of the Hebrew of Origen's Transcriptions, The Academy of the Hebrew Language. Sources and Studies 16 (Jerusalem: The Academy of the Hebrew Language, 2017), and Einar Brønno, Studien über hebräische Morphologie und Vokalismus. Auf Grundlage der mercatischen Fragmente der zweiten Kolumne der Hexapla des Origenes, АКм 28 (Leipzig: Brockhaus, 1943).

62 Brønno, Studien, 3 refers to a letter from Mercati in which he said that he came across this textual witness in 1899, and Brønno also indicates that Ra 271 was used by HatchRedpath and Wutz: E. Hatch \& H.A. Redpath, Concordance, Supplement (Oxford: Clarendon, 1906), 197-216: "Additional Words and Occurrences of Words in Hexaplaric Frag- 
but remained, as far as I know, unpublished until now. Below, I am presenting an edition of these fragments, followed by some editorial comments:

$+\dot{\varepsilon} \beta p \alpha \ddot{\sigma} \sigma \tau i+$

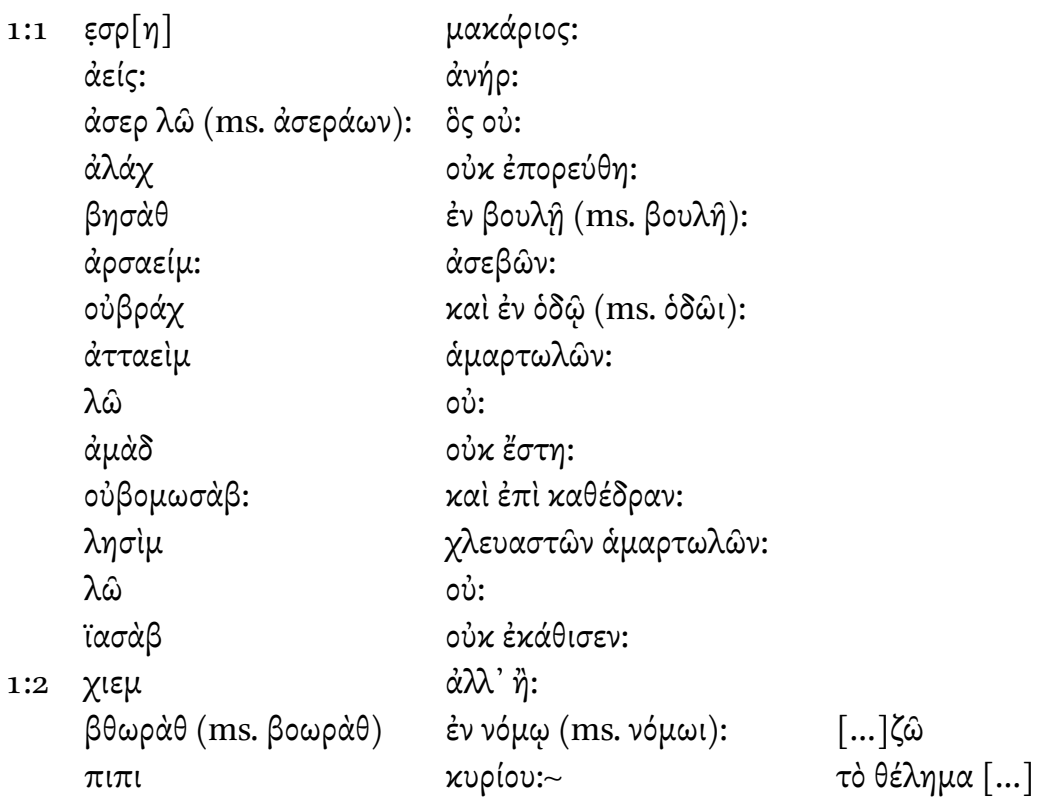

\section{Comments:}

1. From an orthographic point of view, unless otherwise stated, I follow the

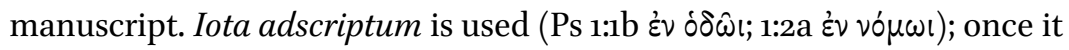

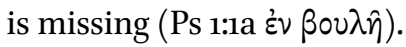

2. The incorrect reading $\dot{\alpha} \sigma \varepsilon \rho \dot{\alpha} \omega \nu$ pro $\dot{\alpha} \sigma \varepsilon \rho \lambda \hat{\omega}$ (Ps 1:1a) presupposes a (direct or indirect) majuscule Vorlage that has been misread: $\Lambda \rightarrow A$.

3. The incorrect reading $\beta$ ow $\rho \dot{\alpha} \theta$ pro $\beta \theta \omega \rho \dot{\alpha} \theta$ (Ps 1:2a) also requires a (direct or indirect) majuscule Vorlage that has been misread: $\Theta \rightarrow O$.

4. The Hebrew negation $\$$ is always represented in the second column with ov่ oủx.

ments"; F. Wutz, Die Psalmen (Munich: Kösel \& Pustet, 1925). The existence of this particular sheet was also indicated by Georg Karo and Hans Lietzmann, Catenarum Graecarum Catalogus (Göttingen: Commissionsverlag der Dieterich'schen Universitätsbuchhandlung Lüder Horstmann, 1902), 43; cf. furthermore Rahlfs, Verzeichnis, 265-266; and Giovanni Mercati, Nuove note di letteratura biblica e cristiana antica, StT 95 (Vatican City: Biblioteca Apostolica Vaticana, 1941), 157 (aggiunte). 
5. The reading $\chi \lambda \varepsilon v \alpha \sigma \sigma \tau \hat{\omega} \nu \dot{\alpha} \mu \alpha \rho \tau \omega \lambda \hat{\omega} \nu$ (Ps 1:1c) combines the Aquila reading $\chi \lambda \varepsilon v \alpha \sigma \tau \hat{\omega} \nu$ (cf. Ra 1175) ad locum with the reading $\dot{\alpha} \mu \alpha \rho \tau \omega \lambda \hat{\omega} \nu$ that is influenced by the context and hence corrupted (cf. Ps 1:1b $\varepsilon v \delta \delta \omega \hat{\omega} \alpha \mu \alpha \rho \tau \omega-$ $\lambda \hat{\omega} v)$.

6. According to Frederick Field, the reading $\varepsilon \dot{\nu} \nu$ vó $\mu \omega$ corresponds to $\alpha^{\prime} \sigma^{\prime} \varepsilon^{\prime}$ $\varsigma^{\prime}$, while $o^{\prime}$ testifies to the article: $\dot{\varepsilon} \nu \tau \hat{\omega} \nu^{\prime} o^{\prime} \mu \omega .^{63}$

In addition, flyleaf 2 of MS Ra 271 contains, as already mentioned, the beginning of LXX Psalm 111 (v. 1a) —a Psalm that starts like Psalm 1 with $\mu \alpha x \alpha$ pros àvíp—in two columns:

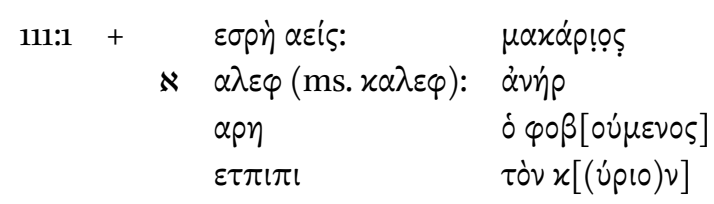

\section{Comments:}

Psalm $111 \mathrm{LXX}$ (112 MT) is one of the alphabetical songs in which each half-verse begins with a letter of the Hebrew alphabet. In our MS Ra 271, the second line of the text transcribed in Greek letters contains the rest of the Hebrew letter aleph misunderstood by the copyist of the manuscript: the manuscript incorrectly reads " $\chi \alpha \lambda \varepsilon \varphi$ " for " $\aleph \alpha \lambda \varepsilon \varphi$." The Hebrew alphabet on the same page can be compared to the shape of the aleph with confusing similarity to the Greek kappa:

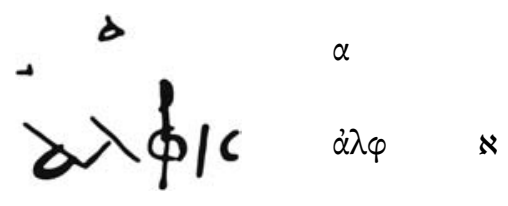

\subsection{Perspectives}

This article has provided insight into some of the challenges of the new longterm research project "Editio critica maior des griechischen Psalters" (Akademie der Wissenschaften zu Göttingen), which started at the beginning of 2020. The transmission problems of the Greek Psalter are extremely complex and require in-depth research. According to Alfred Rahlfs, especially in the case of the Greek Psalter, the Coptic daughter versions of the Septuagint are extremely relevant for understanding the textual history. Therefore, it is particularly for-

63 Field, Origenis Hexaplorum fragmenta II, 87. 


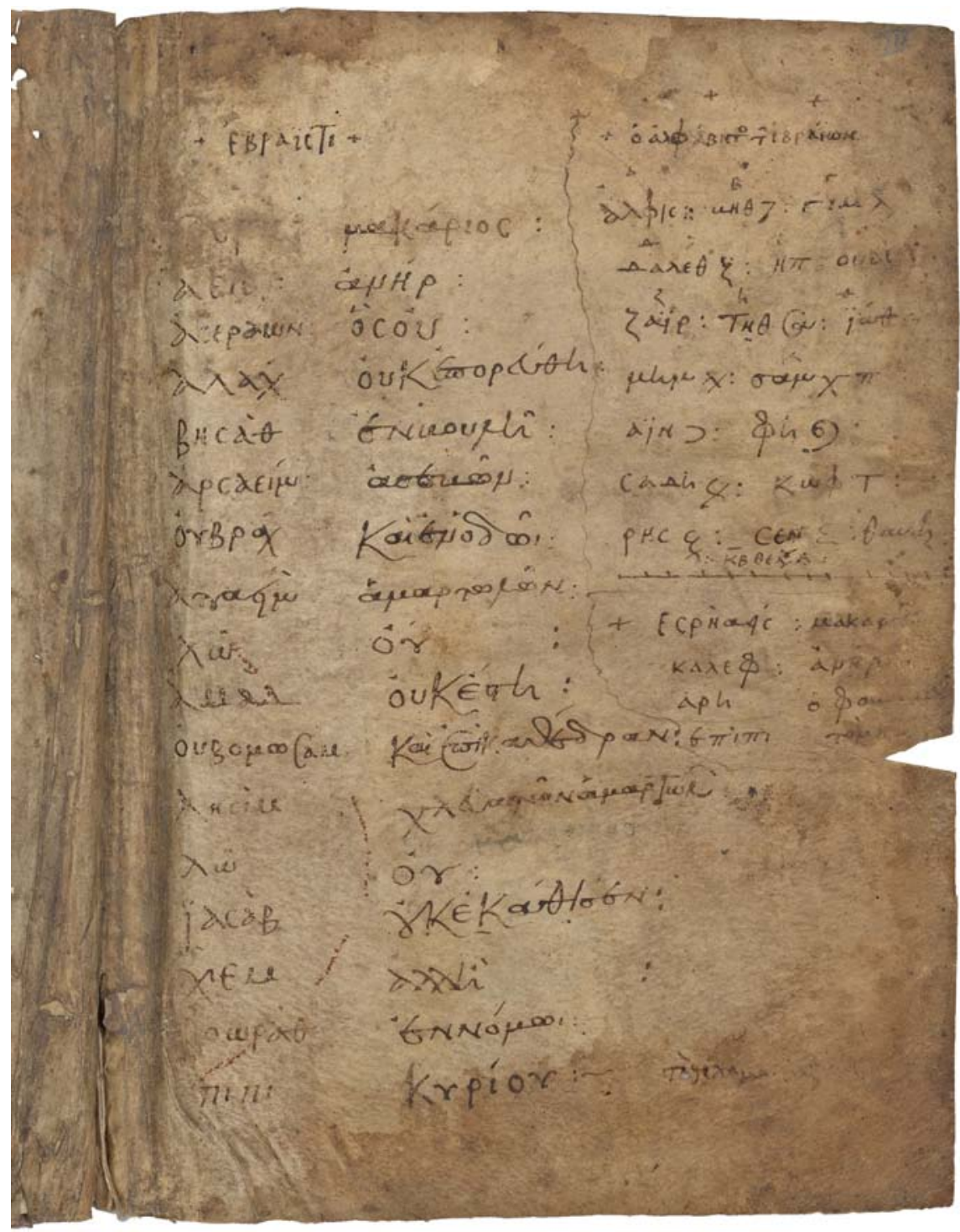

FIGURE 1 Ra 271 (Codex Vaticanus graecus 1747, p. III)

REPRODUCED BY PERMISSION OF THE BIBLIOTECA APOSTOLICA VATICANA, ALL RIGHTS RESERVED

tunate that the other major Göttingen Academy of Sciences and Humanities project on the Old Testament is dedicated to the edition of the Coptic Old Testament. These two projects will work together closely, and I am sure that promising new insights will come to light within the next few years. 